\title{
The Thai/Myanmar border health program: lessons in working with migrant population
}

\author{
Elisabeth Emerson
}

\begin{abstract}
Abstrak
Faktor politik, ekonomi, historis, sosial-budaya dapat menimbulkan masalah kesehatan pada masyarakat migran. Di dunia terdapat beberapa lokasi migran, di antaranya di sepanjang perbatasan Thailand-Myanmar yang diperkirakan lebih dari 1 juta orang Myanmar bermigrasi ke Thailand. Area tersebut merupakan tempat dengan prevalensi tertinggi malaria di Asia dan peningkatan jumlah penderita Tuberkulosis. Kementerian Kesehatan Thailand dan Myanmar mengadakan pertemuan untuk kerjasama untuk menanggulangi masalah kesehatan masyarakat di perbatasan tersebut. Sebagai tindak lanjut pertemuan tersebut, Organisasi Kesehatan se Dunia (WHO) yang ditunjang United Kingdom Department for International Development (DFID), menyediakan dana aktifitas program terebut. Hal ini termasuk diadakannya Program Kesehatan Perbatasan yang dimulai pada tahun 2001. Program ini untuk meningkatkan taraf kesehatan penduduk migrant. Salah satu elemen kunci ialah ialah pengumpulan data dan membuat sistem, koordinasi, pelatihan dan distribusi informasi. Implikasi keberhasilan program terkait dengan koordinasi yang sedang berjalan dengan beberapa pelaku program, termasuk pemerintah, lembaga sosial masyarakat, donor, peneliti, dan beberapa agensi Perserikatan Bangsa-Bangsa $(P B B)$. Beberapa hasil program tersebut dapat dijadikan bahan pembelajaran di tempat serupa yang lain, dan memerlukan penelitian lebih lanjut. (Med J Indones 2008; 17: 43-9)
\end{abstract}

\begin{abstract}
Migrant populations are often vulnerable, and various political, economic, cultural, historical and social situations can make it especially challenging to address public health issues. Not attending to these issues poses increased risks for the migrants, the people in the country they live in, eventually, the rest of the world. There are many locations high density with density population migrants throughout the world, amongst there are the Thailand/Myanmar border it is estimated more than one million migrants have crossed from Myanmar into Thailand. This area has one of Asia's highest malaria infection rates and an increased prevalence of tuberculosis. In 2000, the Ministers of Health of Thailand and Myanmar met jointly to address the public health issues in the border area. Following this meeting the World Health Organization, supported by United Kingdom Department for International Development (DFID), provided funding to support program activities. This included the establishment of the Border Health Program which was initiated in 2001. The Thai/Myanmar Border Health Program sought to improve the health of the most vulnerable populations on the border, and key elements of the program were data collection and system development, coordination, training and information distribution. Implicit to the success of the program was ongoing coordination with the various players, including the governments, nongovernmental organizations ("NGOs"), donors, researchers and UN agencies. Several lessons were learned which can be applied in similar settings, and needs for research and study were identified. (Med J Indones 2008; 17: 43-9)
\end{abstract}

Migrant Health is a global issue. The United Nations estimates that in 2005 there were 191 million migrants worldwide. ${ }^{1}$ About 3 per cent of the world's population live outside their country of birth. In Asia, the number of migrants has increased from almost 28 million in 1970 to 53 million in $2005 .{ }^{1}$

The migrant population raise public health concerns, as the unstructured mobility of any population increases the

WHO Thai/Myanmar Border Health Program Officer, 2001 to 2005 risk of infectious disease transmission. Disease control with mobile population setting is quite challenging. Limitations to health care access, due to geographical, financial, socio-cultural, language or perceived security barriers for migrants poses significant health risk not only for the migrant and his/her family but to the surrounding population. Tuberculosis treatment which requires monitoring drug compliance and follow up for a minimum period of six months is one example of the health challenges faced low compliances and interrupted drug therapy is a contributory factor to multi-drug resistant tuberculosis, another major health issue. Similar challenges are faced with HIV/AIDS, 
malaria and other infectious diseases. The duration of treatment for some diseases, such as malaria, are shorter but the medical regime may be complex.

Migrant health program is relatively new, but it is an emerging area of great importance since accompanying risk of disease transmission and the increasing tendency of migrants worldwide, including in Thai/Myanmar border. The objective of this paper is to describe lessons learned in working with a migrant population health program along the Thai/Myanmar border.

\section{The Thai/Myanmar border situation}

More than one million migrants live in Thailand. ${ }^{2} \mathrm{~A}$ large portion are from neighboring Myanmar and live along the 2,000-km. Myanmar border. Myanmar, then called Burma, obtained independence from Great Britain in 1948.

At that time ethnic groups within Myanmar hoped for autonomy but were included as part of the country of Myanmar. Myanmar is divided into seven divisions and seven states, and part of Myanmar's minority ethnic population live in the four states which border Thailand: Shan State, Kayin State, Kayah State, and Mon State. Each state is populated with unique ethnic groups, having different languages and cultures.

Conflicts between the ruling military regime in Myanmar and the ethnic states increased substantially in the 1980s. At that time a large number of migrants crossed the border into Thailand, fleeing attacks. The first refugee camp for persons from Myanmar was established in Thailand in 1984, the beginnings of a long-term refugee situation. Additional camps were created, and by the end of 2005 the United Nations High Commissioner for Refugees reported that there were 120,000 refugee from Myanmar living in 9 camps in Thailand along the Myanmar border. ${ }^{3}$ A much larger number of migrants live outside the camps.

As conflict continues, access to the population within the ethnic states of Myanmar is controlled and limited. Few non-governmental organizations (NGOs) are authorized to work on the Myanmar side of the Thai/Myanmar border and resources are limited. The Government of Myanmar does not have routine access to rebel-controlled areas, making basic public health initiatives such as immunization challenging.

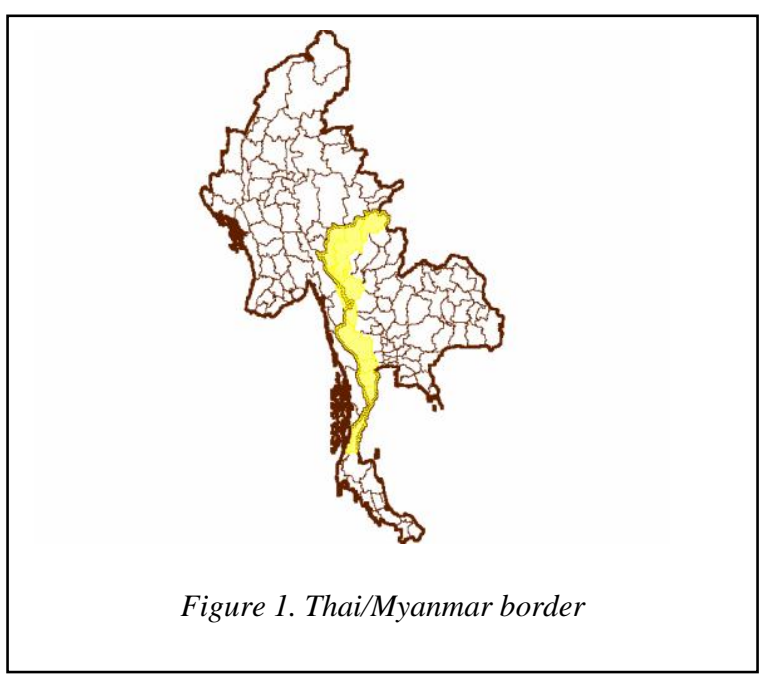

Additionally, the relationship between Thailand and Myanmar has, at times, been conflicting. Increased military tensions resulted in closing the border between the two countries for several months most recently in 2001 and again in 2002.

\section{Migrants from Myanmar in Thailand}

Several factors have to draw migrants from Myanmar across the border into Thailand. Initially migrants crossed the border to escape the political situation, but in more recent years migrants have also been drawn to Thailand in search of economic opportunities. Migrants have provided low-cost labor for factories, orchards and fisheries and as domestic help. Other migrants cross the border to receive medical services, typically at one of the migrant health clinics located along the border or at the medical clinics in the refugee camps. Migrants may also cross for other services, such as education.

Key Public Health Issues along Thai/Myanmar Border:

- Large vulnerable population living in the border areas who do not have adequate access to health services.

- Challenges in addressing public health needs of, as well in collecting data on, this vulnerable population due to security, political, cultural, financial and language barriers.

- Mobility of the population and cross border movement may increase the transmission of disease and result in increasing mortality and morbidity in both the migrants and host populations. 
The Thai Government has pursued a humanitarian policy towards the growing migrant population inside Thailand, and support has also come from agencies working in the border area. The health needs of the camp residents have been addressed by several NGOs. The International Rescue Committee (IRC), ARC International, Medecins Sans Frontieres (MSF), Aide Medicale Internationale (AMI), and Malteser Germany (MHD) have each been in charge of health services in one or more of the total nine camps. While the registered migrant workers have access to government health services, the large number of unregistered migrants receive free diagnostic and treatment services for malaria at government clinics but must pay for all other conditions. They experience multiple barriers in obtaining health services. The mobility of the population and the "underground" nature of their presence, combined with access barriers, are conducive to increased morbidity and mortality of this vulnerable population.

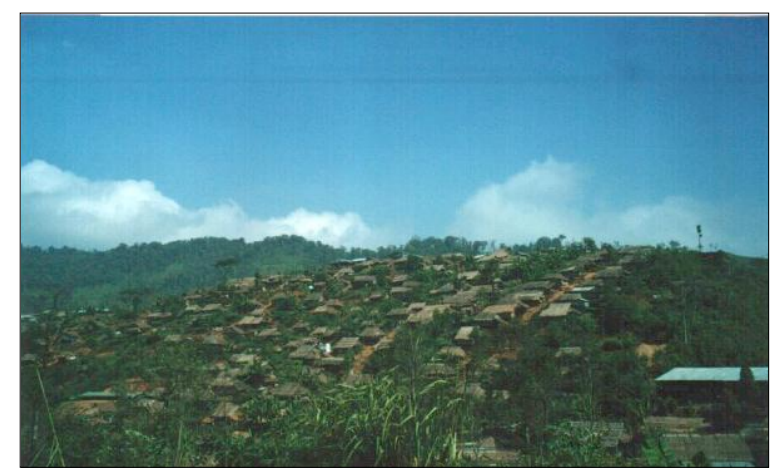

Figure 2. One of 9 camps in Thailand

Some measure of the health status of the migrant population in Thailand has been obtained through government health inspections for migrant workers. During a health inspection by the Royal Thai Government in 2004 and 2005, 3,440 of the 210,948 migrants seeking workers' registration permits were identified as needing follow-up medical care. ${ }^{4}$ Of these, 1,557 were diagnosed with tuberculosis. In 2003 the WHO/MOPH National TB Programme Review recommended special attention be given for the treatment of TB in targeted population groups in Thailand, including migrants and refugee. ${ }^{5}$

While data and reports on the health of the migrant population in Thailand are limited, previous studies showed a rather grim picture. A study by Mahidol University and The Burmese Border Consortium on children five years of age and under living in the camps found that, according to the NCHS standard, $33.7 \%$ were underweight (weight/age < -2 SD), 36.4\% were stunted (height/age $<-2$ SD), and $8.7 \%$ were wasted (weight/height $<-2 \mathrm{SD}$ ). ${ }^{6}$ A study by Walter Reed Army Medical Center, WHO, et al, found that the prevalence of anemia in children from Myanmar in one camp in Thailand was $72 \%$--- higher than the mean prevalence of $49 \%$ for children aged $0-5$ in Southeast Asia. ${ }^{7}$

The incidence of malaria along the Thai/Myanmar border has been one of the highest of the Mekong sub region of Southeast Asia (Thailand, Myanmar, Cambodia, Vietnam, China and Lao PDR). In some parts of the Thai/Myanmar border, the incidence of malaria is more than 50 per 1,000 people. ${ }^{8}$ The Mae Tao Clinic, located in Mae Sot near the border, provides care for migrants from Myanmar. In 2006, malaria accounted for more than $10 \%$ of the Mae Tao Clinic's case load. During the same year, nearly $23 \%$ of all inpatient admissions were due to malaria. Of the 2,022 inpatient malaria patients, $78 \%$ were P. falciparum. ${ }^{9}$

More studies are needed to identify and analyze health risks of the migrant population along the Thai/Myanmar border and in other parts of the world. Without this data, it is less likely that limited resources will be targeted where they are most needed.

\section{Initiatives to address migrant health: joint action plan and border health program}

In July 7-9 of 2000, the Health Ministers of Myanmar and Thailand, along with other public health leaders of both countries, held a meeting in Chiang Mai, Thailand, to discuss border health issues between the two countries and identify strategies for disease control. A "Joint Action Plan for the Myanmar-Thailand Health Collaboration at the Border" was produced, and the World Health Organization ("WHO") funded beginning interventions implemented by the Thailand Ministry of Public Health. These activities targeted malaria, tuberculosis and HIV/AIDS in four border provinces in Thailand and were completed in 2002.

As a complementary activity to the Joint Action Plan, in 2001 the WHO established a Border Health Program in the WHO Thailand Country Office. This program, under the technical supervision of WHO's Division of Emergency and Humanitarian Action, received funding from the United Kingdom Department for International Development (DFID). The program initially focus on strengthening coordination, identifying health problems 
of the migrant population, disseminating information on the health situation in the border area, promoting adoption public health practices and advocates secure humanitarian access. One technical officer was employed, and activities were undertaken in cooperation with the governments of Thailand and Myanmar, the NGOs operating along the border, UN organizations, migrants, research institutions and others who were involved in the public health of the vulnerable migrant population. In 2003, funding was extended for another two years.

The Border Health Program worked collaboratively with the Thailand Ministry of Public Health, and the issue of the refugee became more prominent on the agenda of the Thailand Ministry of Public Health. Studies and discussions on the border population contributed to the development of a Border Health Master Plan and a Migrant Health Information System within the Thailand Ministry of Public Health. Plans were begun to establish a Border Health Coordinating Committee in the Ministry of Public Health.

\section{Key activities of the border health program}

The overall objective of the program was to improve the health of the population in the border areas of Thailand and Myanmar, with a special focus on the health and humanitarian aspects of the most vulnerable groups.

Activities included initiating coordination meetings, promoting standardization of data collection on migrants, initiating development of a migrant health information system, developing a database of studies and assessments that had been done in the border area, compiling existing research and other information related to migrants into an accessible format, obtaining funding to improve primary health care services to migrants in the border areas, supporting outreach activities to vulnerable populations, and distributing technical publications and information to health workers in the border areas.

Three areas of the Program, coordination, data collection and the maternal and child health booklet, are highlighted in this section.

\section{Coordination}

A key function of the Border Health Program was bringing together players from various backgrounds and agendas to discuss shared public health concerns along the border. Initially, coordination meetings were scheduled to focus on general issues. A large general meeting, with opportunities for organizations to display their activities, was held in different locations along the border once a year. As people began to work together more closely, additional coordination meetings began to target specific diseases such as malaria and tuberculosis. Coordination meetings helped support an update in Thailand's malaria policy.

In addition to specific medical issues, coordination meetings were aimed at geographic regions or stakeholders. Recognizing that UN agencies were not always aware of each other's activities, a UN Border Health Coordination Meeting was scheduled every other month. It was attended by representatives of the national government, as well as UN representatives, and during each meeting a presentation on one aspect of border health was given. Realizing more coordination was needed in the local areas, Provincial Health Coordination Meetings were established in each province. These were attended by local health officials and NGOs. Though politically challenging, coordination meetings between the local health officials of Mae Sot in Thailand and Myawaddy, across the border in Myanmar, were also organized.

In addition to coordination meetings, various players were brought together through training sessions and efforts to mobilize resources. One example of the latter occurred in 2003 when Thailand and Myanmar submitted a joint application for funding in the first round of the Global Fund. While the Global Fund application was not approved, it was successful in that it provided a non-threatening forum for public health officials from Myanmar and Thailand to get together and discuss politically sensitive issues related to the public health of the displaced border population. The meetings to work on the Global Fund were opportunities to exchange information and get to know public health counterparts in Thailand and Myanmar. Following the Global Fund application, more cross-border activities were possible.

\section{Data collection initiatives}

A challenge in working with the migrant population in Thailand was the lack of adequate health data to identify the most urgent public health problems and to target the populations in greatest need with the appropriate interventions. Collecting data is often difficult due to migrant population mobility and their legal status. Migrants, particularly those who are illegal, may reject any record of their presence. While 
a number of studies and reports had been done on migrants in Thailand, the data collected was not always comparable and it was not always shared and accessible to others. The government, NGOs and others who wished to support activities for migrants faced a gret deal of uncertainty in determining what the greatest needs were and where they were. Addressing this issue, coordination meetings were held with the Bureau of Epidemiology at the Thailand Ministry of Health, the International Organization of Migration, NGOs and other players involved in or interested in data collection on migrants.

At the Data Coordination Meetings an attempt was made to link new efforts with existing initiatives. NGOs and the Ministry of Public Health had developed and begun to use a communicable disease surveillance system in the camps in 2002. The Mae Tao Clinic, a clinic serving migrants and non-migrants, had developed a health data collection tool for migrants and was beginning to gather data. Both the surveillance system and the data collection tool were taken into account in creating new data initiatives.

While many technical resources are available for collecting data on non-migrant populations, little is available on how to deal with the unique aspects, such as mobility, of the migrant population. Without any model to follow, the need to develop a migrant health information system in Thailand was recognized. Support was provided to establish a new position, "Migrant Health Technical Officer," in the Ministry of Public Health, Bureau of Epidemiology. A data collection tool was developed and field tested, involving the input of government and non-government players. More long-term funding to support this position was needed, and funds to develop the migrant data system were requested from the Human Security Fund. The funding request, submitted by the World Health Organization and the International Organization of Migration, was approved, and funds were received in 2005. With these funds, a "Migrant Health Information System" has been established in the Ministry of Public Health. The person who was involved in the creation of the successful communicable disease surveillance system in the camps is in charge of developing the migrant health information system.

While the development of the Migrant Health Information System in Thailand will provide a good model, more work in the area of migrant health data collection is needed so that tools and resources are available for differing migrant situations worldwide.

\section{Maternal and child health booklet}

Concerned about the lack of health information on the mobile migrant population, this booklet was developed for use by migrant mothers and children from Myanmar. This small plastic-covered book contains essential medical information and can easily be transported from one country to another.

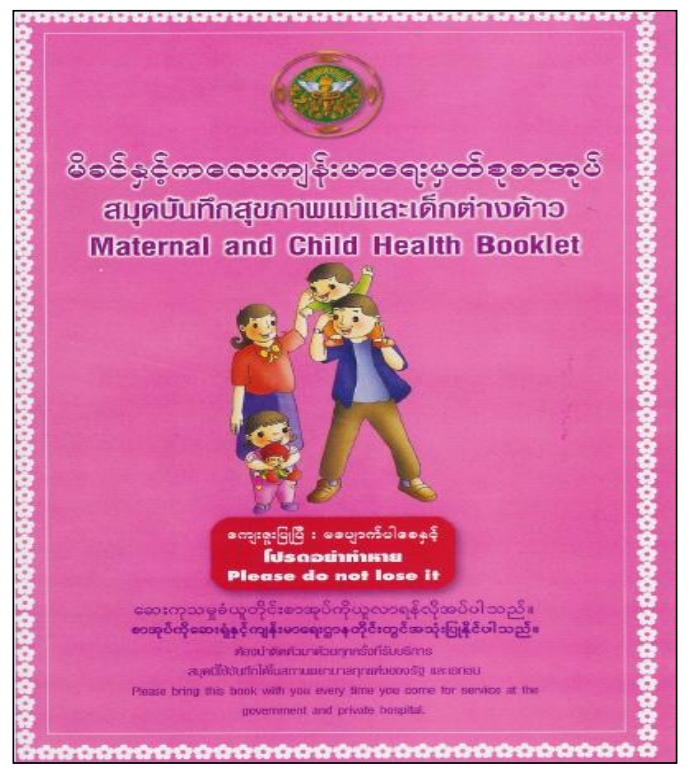

Figure 3. Maternal and Child Health Booklet

Modeled after the Thailand Government's Maternal and Child Health "pink book," the "Maternal and Child Health Booklet" was written in Thai, Burmese and English. English was used, as it was generally understood by internationals working in the area and it would make the information recorded easier to understand for those who might be resettled in another country.

The "Maternal and Child Health Booklet" contains space to record immunizations, growth and medical history, as well as areas to record appointments, birth information, general health history, and records of postpartum check ups. Some health education is included, as is a pregnancy risk assessment.

The book was developed collaboratively with the Thailand Ministry of Health and various groups who were active in the border areas. A draft copy was sent Myanmar Ministry of Public Health for review, and suggested changes were incorporated. Thousands of copies of the book were distributed to migrant mothers and children at no cost throughout the 2,000-km. Thai/Myanmar border. 
This small booklet has been used successfully, and perhaps standardized migrant health record books for migrants of all ages should be considered. While changes would be needed to respect cultural and language differences, having the same basic information may support better medical record keeping for all migrants.

\section{Stakeholders response}

At the end of five years, government representatives from Thailand and Myanmar, NGOs, UN agencies and others who were involved in the Border Health Program were asked for input on whether or not the program had been beneficial. Most respondents cited the coordination aspect as the most valuable part of the Program to them. The primary benefit of coordination was the opportunity to construct networking with other partners and identify opportunities for collaboration. The cross-referrals between agencies made it possible to pool and coordinate their efforts, minimizing waste.

The annual border health meeting, with participants from both Thailand and Myanmar, was especially well received. Respondents felt it created small opportunities for collaboration which later developed into important event. For some, the annual meeting provided a glimpse of what was happening on the other side of the border from where they worked. As the technical meetings began to be held more regularly and attendance increased, greater opportunities were provided for governments and international agencies to communicate on a more regular basis without suspicion.

The sharing of information was rated high. Respondents were particularly positive about the public health surveillance data from the camps, information on the infrastructure in the provinces (NGO and government) and the estimated populations of migrants. Respondents felt they could access reports, otherwise unavailable.

As far as suggested changes for the future, respondents indicated they would like more cross-border activities, they would like to see the development of a migrant health information system, and they definitely wanted the meetings to continue.

\section{Conclusions}

The Border Health Program was a unique program, with no previous model. It identified successful approaches for working with migrants in this particular situation, as well as identifying areas of future studies.
In situations such as the Thailand/Myanmar border where there are multiple players, conflicting missions and differing cultures and political views, the challenge of establishing effective public health programs can be substantial. It is important to bring various groups together so key players can talk and understand each other's objectives and points of view. Working together, it is more likely needs and issues will be identified and collaborative activities will begin. In addition to meetings, coordination can be achieved through newsletters, e-mails, web sites and any other means of communication. It is important to have lists of the players, along with contact information, so people can get in touch with one another.

Without adequate data, it is difficult to identify the needs of any population and use limited resources most appropriately. No system is established get for collecting and maintaining data on migrants, but Thailand is attempting to develop one. While a data system is being developed, it is important to compile studies which have been done on the migrant population and make this information available to those who are planning initiatives.

More research and study is needed in the development of standardized medical records book which can be used by displaced populations worldwide.

To be effective, this program must consistently advocate the mission of public health but remain apolitical. Focusing on the critical need to optimize the health of all people, especially the most vulnerable, can help depoliticize sensitive issues.

The preamble to the World Health Constitution includes a statement which holds very true in these working environments: The enjoyment of the highest attainable standard of health is one of the fundamental rights of every human being without distinction of race, religion, political belief, economic or social condition.

\section{Acknowledgement}

The author would like to acknowledge the work of the public health workers from the governments of Thailand and Myanmar; the non-governmental organizations, donors, UN agencies and researchers working along the Thai/Myanmar border; and all others committed to improving the health of the migrants and refugees currently living in Thailand. Without their contributions, the accomplishments noted in this report would not have been possible. In preparing this report, special gratitude is given to Prof. Bastaman Basuki for his wise 
counsel and technical assistance and to Dr. Johanna Larusdottir for her valuable input.

\section{REFERENCES}

1. World Migrant Stock: The 2005 Revision Population Database [database on the Internet]. New York, New York: United Nations. c2006 - [cited 2007 September 25] Available from: http://esa.un.org/migration

2. Huguet JW, Punpuing S. International migration in Thailand. Bangkok, Thailand: International Organization for Migration; 2005.

3. United Nations High Commissioner for Refugees. 2005 global refugee trends [monograph on the Internet]. Geneva, Switzerland: UNHCR. 2006 June 9 [cited 2007 September 25] Available from: http://www.unhcr.org/ statistics/STATISTICS/4486ceb12.pdf

4. Bureau of Health Systems Development, Thailand Ministry of Public Health as of February 3, 2005.
5. SEAR Reports. Third review of the national tuberculosis program in Thailand, 17-28 November 2003, SEA-TB267, 2004.

6. Banjong O, Menefree A, Srancharoenpong K, Chittchang U, Eg-kantrong P, Boonpradem, A, Tamachotipong S. Dietary assessment of refugees living in camps: A case study of Mae La Camp, Thailand. Food and Nutrition Bulletin. 2003: 24:360-67.

7. Kemmer TM, Bovill ME, Kongsomboon W, Hansch SJ, Geisler KL, Cheney C, et al. Iron deficiency is unacceptably high in refugee children from Burma. J Nutr. 2003; 133:4143-9.

8. SEAMEO Regional Tropical Medicine and Public Health Network. Mekong Malaria II: Update of Malaria, MultiDrug Resistance and Economic Development in the Mekong Region of Southeast Asia. Southeast J Trop Med Pub Health. 2003:34 (Suppl 4):S45-50.

9. Mao Tao Clinic. Annual Report 2006. Mae Sot, Thailand: 2007. 2007 [cited 2007 September 25] Available from: http://www.maetaoclinic.org 